УДК 902.1 (571.63)

https://doi.org/10.24852/2587-6112.2021.4.45.56

\title{
КУМИРНЯ БОХАЙСКОГО ВРЕМЕНИ В ЮЖНОМ ПРИМОРЬЕ ${ }^{1}$
}

\author{
() 2021 г. Н.А. Клюев, С.Д. Прокопец, И.Ю. Слепцов, И.В. Белова
}

Находки раннесредневековых буддийских культовых сооружений являются достаточно редкими в приморской археологии. Данная работа посвящена исследованиям кумирни, обнаруженной в Южном Приморье. В научный оборот вводятся результаты раскопок 2010-2011 гг., в ходе которых были вскрыты остатки культового сооружения с черепичной крышей, обнесенного оградой, а также обнаруженный археологический материал. Коллекция найденных предметов включает в себя многочисленные обломки черепицы, ритуальную посуду, представленную чашечками-светильниками и триподами, изделия из металла и камня. Археологический материал находит аналогии на памятниках бохайского времени на территории Приморья, в том числе храмовых комплексах этого периода.

Ключевые слова: археология, государство Бохай, раннее средневековье, буддизм, кумирня, ритуальный комплекс, Приморье, «Барабаш-3. Кумирня».

\section{IDOL TEMPLE OF THE BOHAI PERIOD IN SOUTHERN PRIMORYE ${ }^{2}$}

\section{N.A. Kluyev, S.D. Prokopets, I.Yu. Sleptsov, I.V. Belova}

The discovery of early medieval Buddhist religious buildings is quite rare for the archaeology of Primorye region. The paper is dedicated to the study of an idol temple discovered in Southern Primorye. The results of 2010-2011 excavations are introduced into scientific discourse, during which the remains of a fenced religious building with a tiled roof, as well as archaeological material discovered inside, were revealed. The collection of finds includes numerous fragments of roof tiles, ritual dishware represented by cups-lanterns and tripods, metal and stone artefacts. Counterparts to the archaeological material have been found at the sites of the Bohai period in the territory of Primorye region, including the temple complexes of this period.

Keywords: archaeology, Bohai state, early Middle Age, Buddhism, idol temple, ritual complex, Primorye, "Barabash-3. Idol Temple".

Культовая архитектура является неотъемлемым элементом жизни восточно-азиатского мира. Приморский край в этом плане не является исключением. Начиная с раннего Средневековья, в результате прихода буддизма, на этих землях появляются различные храмовые постройки. Считается, что подобные сооружения начинают возводиться на приморских землях в период процветания государства Бохай, под влиянием соседей - корейских государств и китайской империи Тан (Стоякин, 2012; Асташенкова, 2013).

К настоящему времени в Приморском крае обнаружено и исследовано пять храмов (Абрикосовский, Борисовский, Копытинский, Корсаковский, Краскинский), которые датированы бохайским временем (Государство Бохай..., 1994, с. 81-91; Города средневековых..., 2018, с. 20; Медведев, 1998). На территории Китая известно еще девять бохайских храмов, а на территории Северной Кореи - два (Стоякин, 2012). Таким образом, общее коли-

чество открытых археологических объектов подобного назначения для столь обширного региона невелико, что повышает значимость каждой новой находки. К их числу относится и кумирня, обнаруженная на памятнике Барабаш-3 (Клюев и др., 2011).

Памятник Барабаш-3 находится на юге Приморского края, в 7 км к юго-востоку от пос. Барабаш. Он занимает южную оконечность узкого мысовидного отрога, вытянутого с юга на север. Высота мыса составляет 8-10 м. На западе он обрывается старичной протокой, на юге - непосредственно р. Барабашевкой. Восточный пологий склон спускается в долину реки, постепенно переходя в трёхметровую пойменную террасу. На севере мыс смыкается с невысоким горным хребтом. Памятник многослойный и представлен материалами разных эпох: среднего и позднего неолита (бойсманская и зайсановская археологические культуры), раннего железного века (янковская археологическая культура),

1 Часть работы, выполненная Клюевым Н.А. и Беловой И.В., осуществлялась в рамках реализации гранта РНФ № 20-18-00081 «Археология Дальнего Востока России».

2 Part of the work performed by N.A. Klyuev and I.V. Belova was carried out within the framework of the grant of the Russian Science Foundation No. 20-18-00081 “Archaeology of the Russian Far East”. 


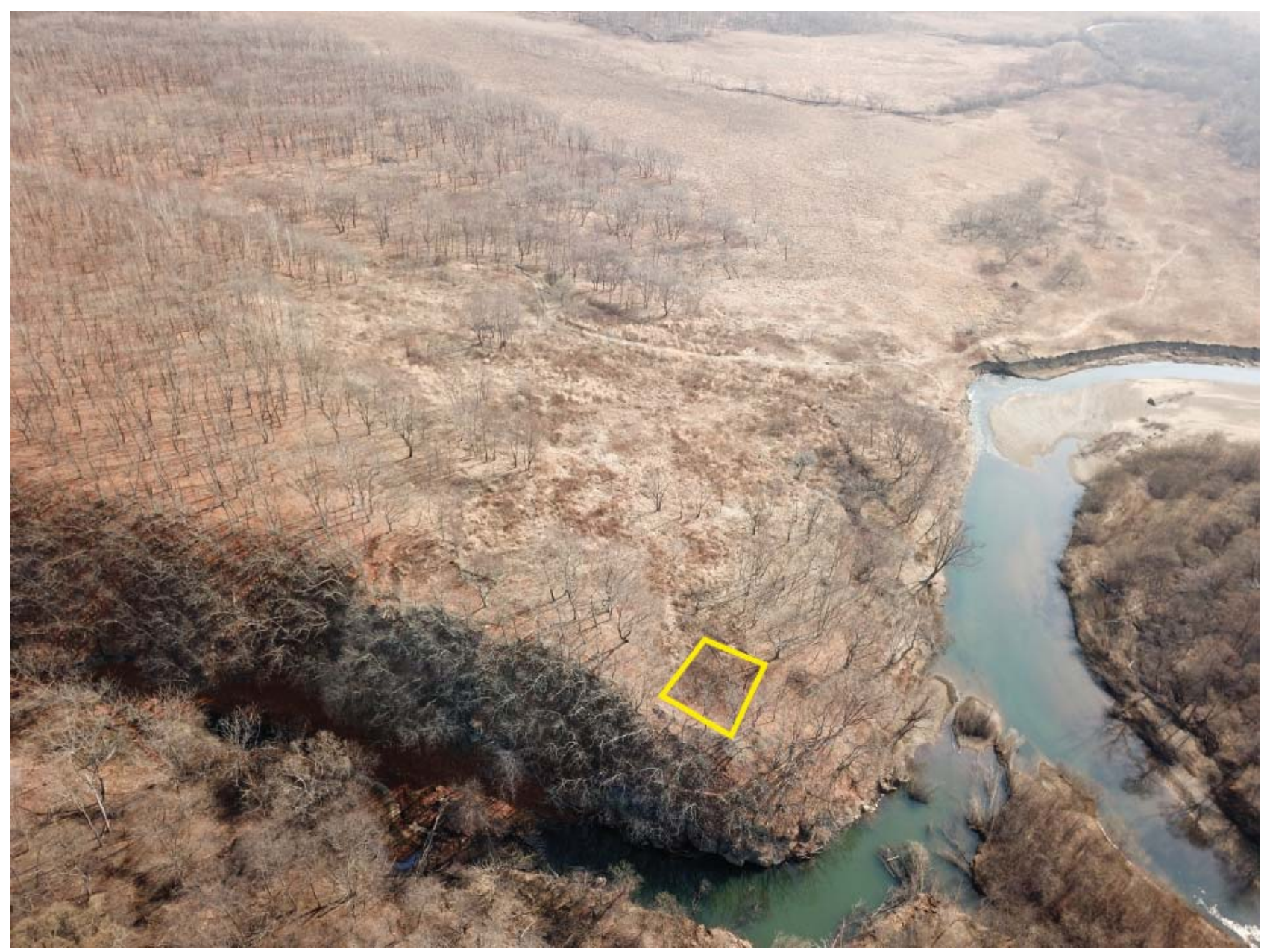

Рис. 1. Общий вид на мыс с юго-запада с обозначением раскопа объекта «Барабаш-3. Кумирня»

Fig. 1. General view of the cape from the southwest with the designation of the excavation site of the "Barabash-3. Idolatry"

a также раннего Средневековья (мохэская культура и государство Бохай). Основным на памятнике является слой раннего железного века - янковской археологической культуры, который выделяется как стратиграфически, так и планиграфически. Место было удобно для расположения янковского поселения, которое было защищено с трех сторон резким мысовым обрывом, а в северной части отделено земляным валом (ширина - 3 м, высота - 0,5 м, длина - 25 м), который тянется через весь мыс (Клюев, Гридасова, 2013, с. 150-151).

При определении границ янковского поселения в южной части памятника Барабаш-3 в шурфе была обнаружена средневековая черепица, залегавшая in situ, без признаков переотложенности. Характер залегания археологического материала в слое, а также топографические и планиграфические особенности места, где был заложен шурф, указывали на существование в данном месте объекта, культурно и хронологически не связанного с изучаемым поселением раннего железного века, но вместе с тем расположенного в его границах. Дальнейшие раскопки показа- ли, что остатки постройки под черепичной крышей принадлежат культовому сооружению бохайского времени, которое получило название «Барабаш-3. Кумирня» (рис. 1).

Объект «Барабаш-3. Кумирня» изучался Клюевым Н.А. на протяжении двух полевых сезонов в 2010-2011 гг. Общая площадь раскопа, заложенного на южной оконечности мыса, составила $234 \mathrm{~m}^{2}$. В западной части раскоп был ограничен остатками военной траншеи, расположенной у края обрыва.

Мощность напластований в раскопе колеблется от 10 до 60 см, в зависимости от конфигурации рельефа и результатов антропогенного воздействия. Вся площадь раскопа перекрыта слоем дерна мощностью 6-11 cм. Дерн подстилает пачка неоднородно окрашенной буровато-коричневой супеси, включающей в отдельных местах обломочный материал (камни), мощностью 10-50 см. В свою очередь, буровато-коричневая супесь перекрывает линзы гумусированной буро-коричневой супеси с включением дресвы (остатки янковского культурного слоя) мощностью до 17 см, которая в подошве переходит в светло- 


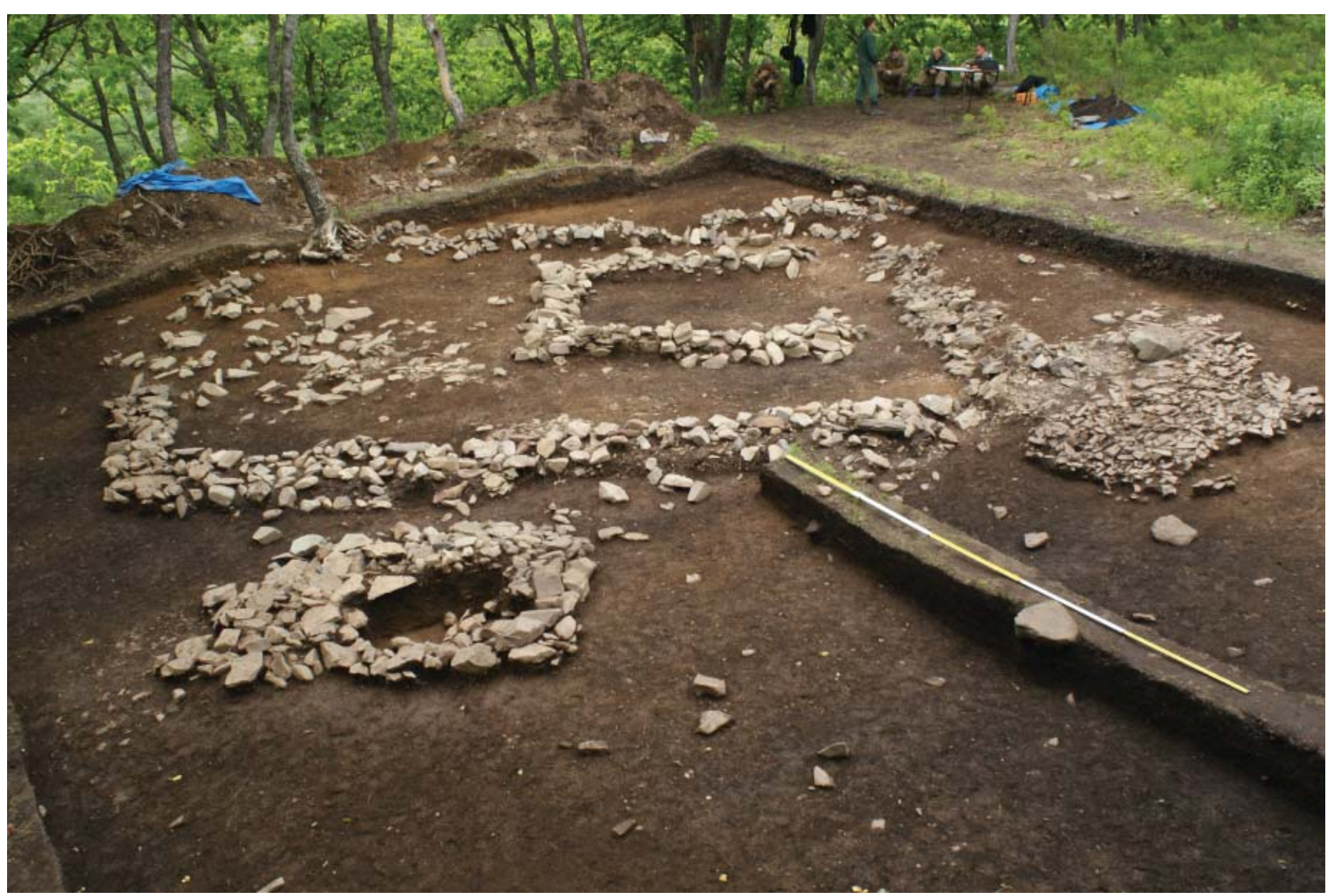

Рис. 2. Общий вид ритуального комплекса с юго-востока

Fig. 2. General view of the ritual complex from the southeast

коричневый плотный суглинок, насыщенный дресвой (материк).

В результате исследований были вскрыты остатки культового сооружения, представляющего собой небольшую постройку, обнесенную оградой, от которой сохранился сложенный из камня фундамент стен, частично перекрытый многочисленными обломками черепицы (рис. 2, 3).

Квадратное основание стен кумирни имеет размеры по внешней стороне $4,2 \times 4,4$ м и площадь $18,5 \mathrm{~m}^{2}$. Сооружение ориентировано углами по сторонам света. Ширина каменного фундамента достигает 50 см, высота 40 см. В северо-восточной стене прослежен разрыв шириной 1,8 м, который мог служить входом в кумирню. В этом же месте был найден замок. По углам кладки фундамента располагались крупные камни с плоской поверхностью - опоры для столбов. С внешней стороны кумирни находился фундамент ограды павильона кумирни, который также был ориентирован углами по сторонам света. Ограда прямоугольной в плане формы, размерами $8 \times 10$ м, вытянута по линии юго-запад северо-восток. Планиграфически сама кумирня смещена к северо-западному углу ограды, благодаря чему в южной части был образо- ван внутренний дворик. Вход в этот дворик оформлен разрывом в южной стене ограды. Во внутреннем дворике напротив входа, на расстоянии 1,2-1,4 м, расположены две ямы от столбов, возможно, связанные с конструкцией ворот. Расстояние между столбовыми ямами составляет 2 м.

С внешней стороны восточной стены ограды кумирни, на расстоянии 0,8-1 м, обнаружена каменная выкладка подпрямоугольной в плане формы размерами $3,2 \times 2,5$ м. Длинная сторона выкладки параллельна ограде кумирни. В центре выкладки зафиксирована овальная яма, заполненная гумусированной буровато-коричневой супесью. Размеры ямы $-1,8 \times 1$ м, глубина в центре выкладки - 44-46 см. В заполнении ямы найден крупный фрагмент бохайского сосуда и мелко фрагментированная керамика янковской культуры. Яма была забутована крупными камнями. К востоку от каменной выкладки зафиксировано скопление обломком черепицы. Вероятно, каменная выкладка представляет собой остатки какогото небольшого сооружения с черепичной крышей.

Найденный в ходе работ археологический материал раннего Средневековья, относящийся к исследуемому культовому комплек- 


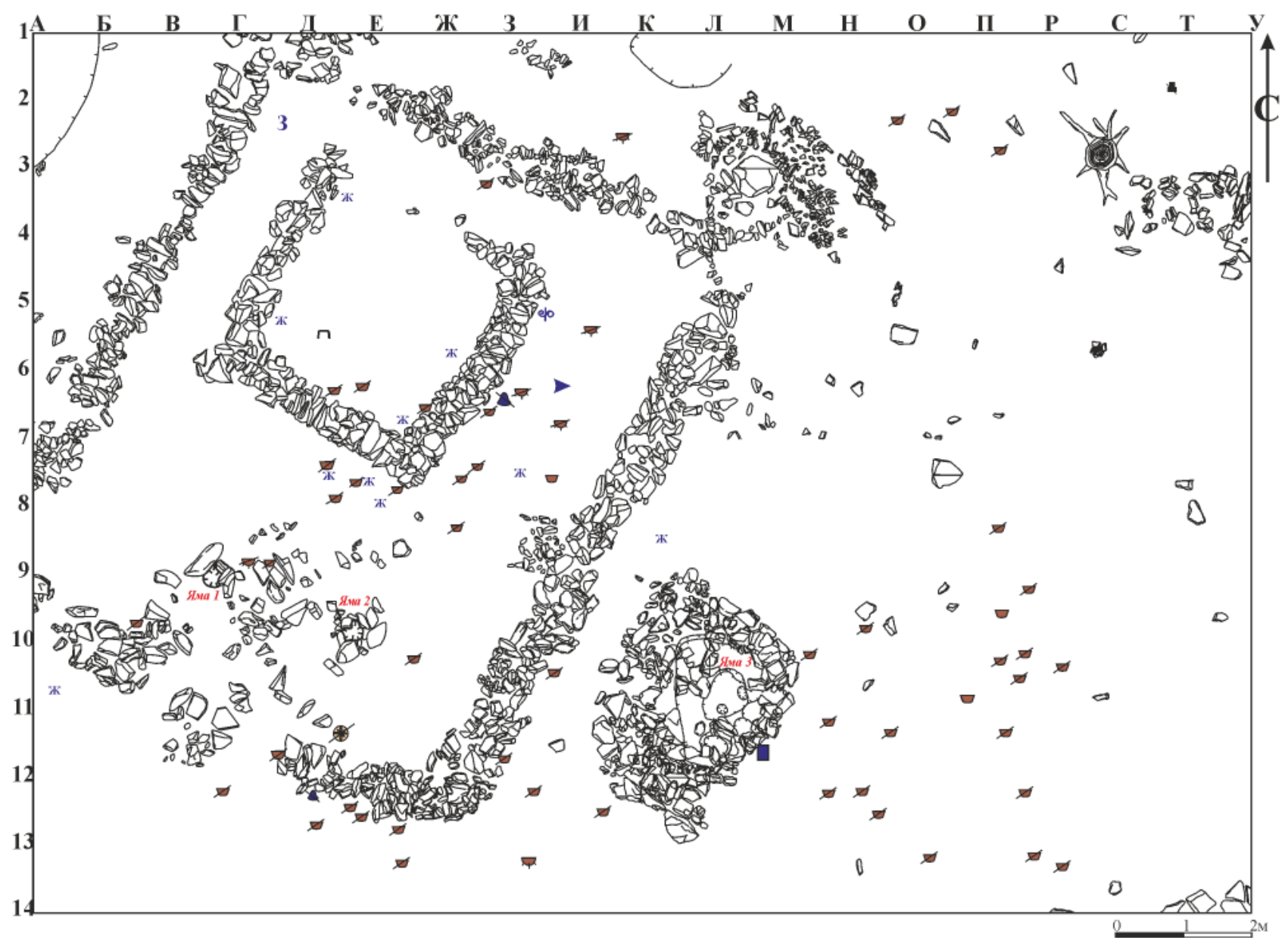

Условные обозначения:

\begin{tabular}{|c|c|c|c|}
\hline$\nabla$ & - ритуальная чашка & eqo & - колокольный вертлюг \\
\hline$\not$ & - фрагмент ритуальной чашки & a & - фрагмент колокола \\
\hline ד & - фрагмент трипода & $\sqcap$ & - скоба \\
\hline 車 & - фрагмент концевого диска черепицы & 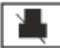 & - обломок каменного постамента \\
\hline 3 & - деталь замка & $>$ & - железный наконечник \\
\hline 口 & - железная пластина & Ж & - фрагмент железного изделия \\
\hline
\end{tabular}

Рис. 3. План раскопа с распространением находок.

Fig. 3. Plan of the excavation with the distribution of the finds

су, составляет 6147 артефактов. Из них 5958 экземпляров - это обломки черепицы, $89-$ фрагменты ритуальных чашечек, 10 - обломки триподов, 1 - фрагмент концевого диска, 16 изделия из металла и их обломки, 1 - нижняя часть каменного постамента. Небольшое количество артефактов представлено разрозненными фрагментами круговой посуды.

Черепища является наиболее многочисленной частью коллекции. Для ее изготовления использовалась запесоченная глина с разнозернистым отощителем с размером частиц $0,1-0,5$ см. Черепица формировалась на шаблонах, обтянутых тканью, спирально ленточным способом, затем поверх- ность выбивалась лопаточкой-колотушкой, обмотанной нитью, и на конечном этапе поверхность заглаживалась. Цвет черепицы светло-коричнево-красный, оранжевый, светло-оранжевый, светло-оранжево-желтый, серый. Вся черепица подразделяется на два вида - нижнюю и верхнюю (рис. 4).

Нижняя черепица более широкая с плавным сводом, ее длина составляет 42 см, ширина -32 см, толщина варьируется от 1,8 до 2,4 cM.

Верхняя черепица уже, а по форме напоминает половину рассеченного вдоль цилиндра, сужающегося к одному концу. Длина верхней черепицы составляет 37,4-37,8 см, ширина у 

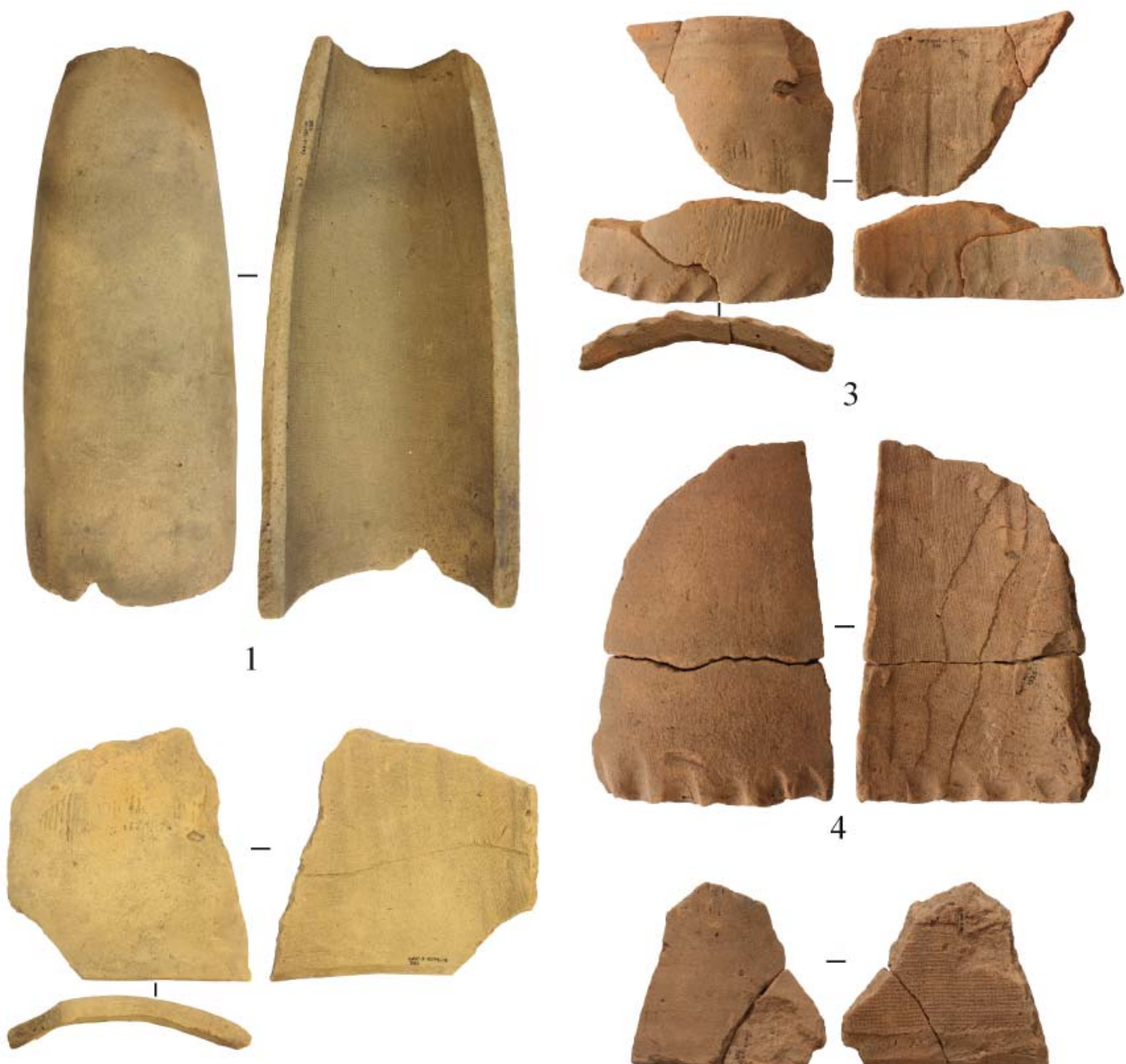

3

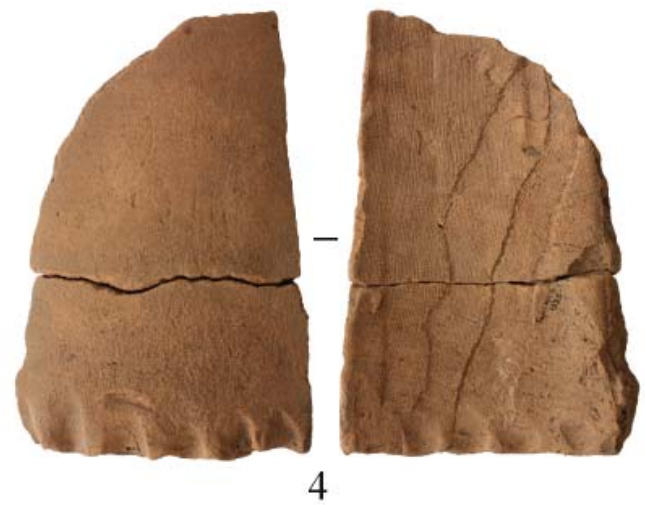

2
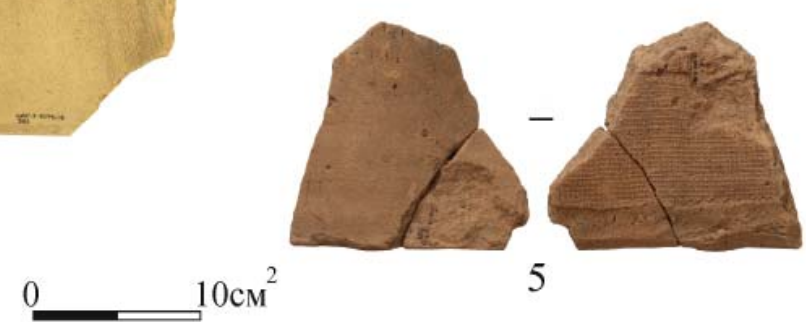

5

Рис. 4. Обломки черепицы

Fig. 4. Fragments of the roof tiles

широкого торца - 16,5 см, у узкого - $11 \mathrm{cm,}$ толщина - 1,7 см. На внутренней поверхности, как верхней, так и нижней черепицы, видны отпечатки ткани и шаблона, на котором она изготавливалась. Торцевой край слегка загнут вверх и имеет орнамент, выполненный пальцевыми вдавлениями (рис. 4: 3, 4). При стандартных размерах и сходных техникотехнологических признаках нижняя черепица отличается цветом и видом орнамента.

Среди кровельного материала присутствует только один обломок концевого диска, который был обнаружен на месте предполагаемого входа во двор кумирни (рис. 3, 7: 6). Он представляет собой сегмент диска серого цвета, орнаментированного стилизованным изображением цветка лотоса. Диаметр диска составлял около $13 \mathrm{~cm}$, толщина $-1 \mathrm{~cm}$. По кромке имеется прикрепленный ободок высотой 0,9 см и толщиной 1,2 см. Точные аналогии изображению на концевом диске обнаружить не удалось, но общая стилистика орнамента характерна для бохайского времени (Асташенкова, Болдин, 2004; Бохайские древности..., 2013, с. 74-76, 91-94, 100-104, 130-134).

Ритуальная посуда представлена многочисленными обломками небольших чашечек, а также двумя триподами с обломанными ножками. Фрагменты ритуальных чашечек обнаружены как внутри, так и за пределами кумирни и ее ограды (рис. 3). Из 89 найденных обломков удалось полностью или частично реконструировать только 10 экземпляров (рис. 6: 3-12). Для их изготовления, скорее всего, использовалась глина с естественным содержанием незначительного количества песка. Размер частиц песка варьируется от 0,1 до 1,5 мм. Почти все чашечки были вытянуты из одного куска глины на гончарном круге. В четырех случаях днища были прикреплены к стенкам. Поверхность сосудов выглаживалась. По окончании изготовления сосуды снимались с гончарного круга после его 


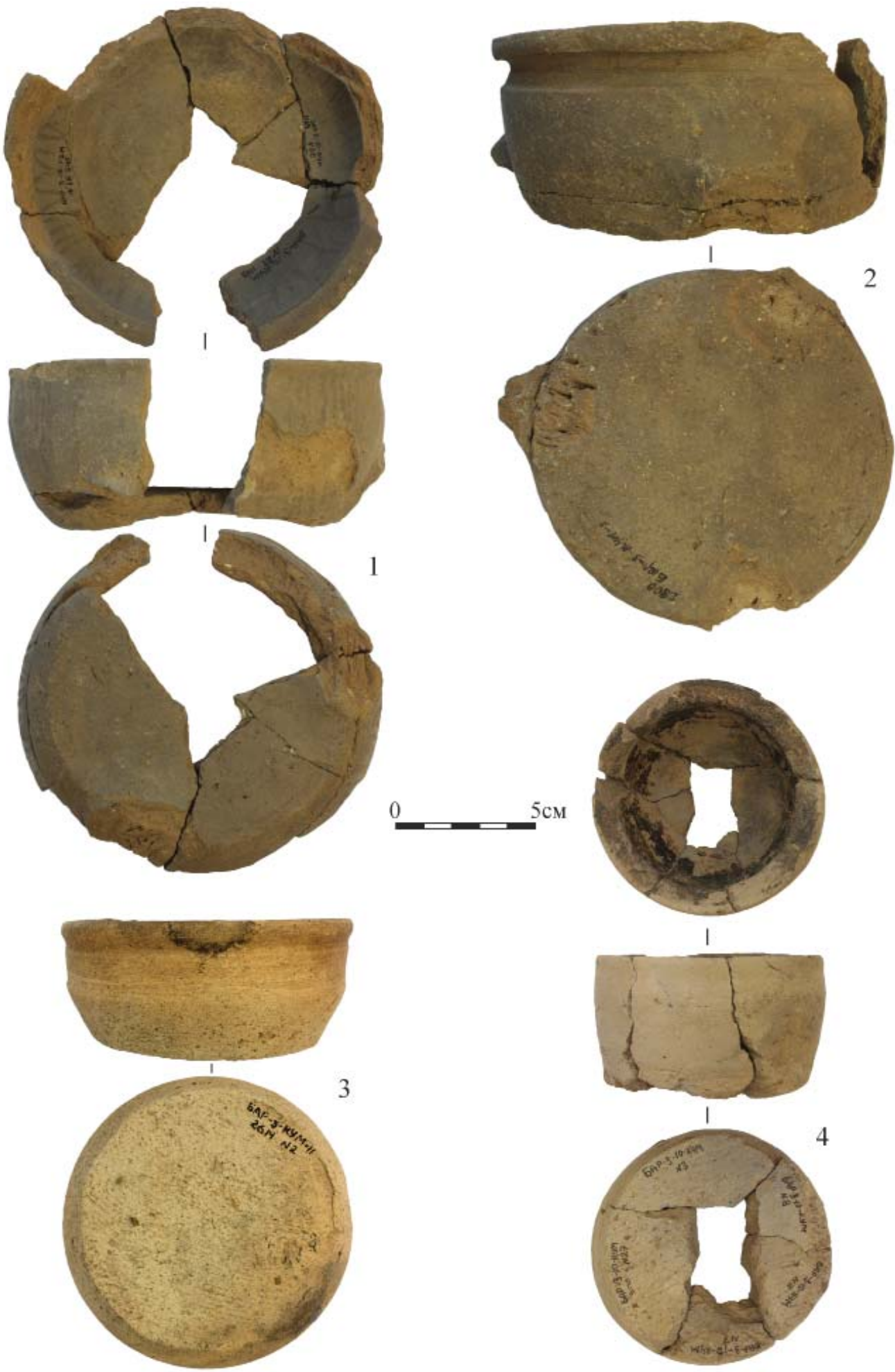

Рис. 5. Ритуальная посуда: 1, 2 - триподы; 3, 4 - чашечки-светильники

Fig. 5. Ritual dishes: 1, 2-tripods; 3, 4-cups-lamps

полной остановки при помощи шнура, о чем говорят параллельные бороздки на днищах (рис. 5: 3, 4). Из восьми археологически целых чашечек такие следы остались у четырех экземпляров. Остальные днища либо обточены, либо заглажены. Большая часть керамики обжигалась в восстановительном режиме. Вместе с тем зафиксировано, что пять сосудов обжигались в окислительном режиме, а один - в окислительном, с дымлением в конце обжига. На трех экземплярах фиксируются следы пережога. Все чашечки имеют примерно одинаковые размеры: диаметр венчика $8,2-10,8$ см, диаметр дна $-5,3-7,9 \mathrm{~cm}$, высота $-4,5-5,9$ см, толщина стенок $-0,5-0,9$ см. На внутренней стороне большинства чашечек имеются следы черного нагара, что свидетельствует об их длительном использовании 

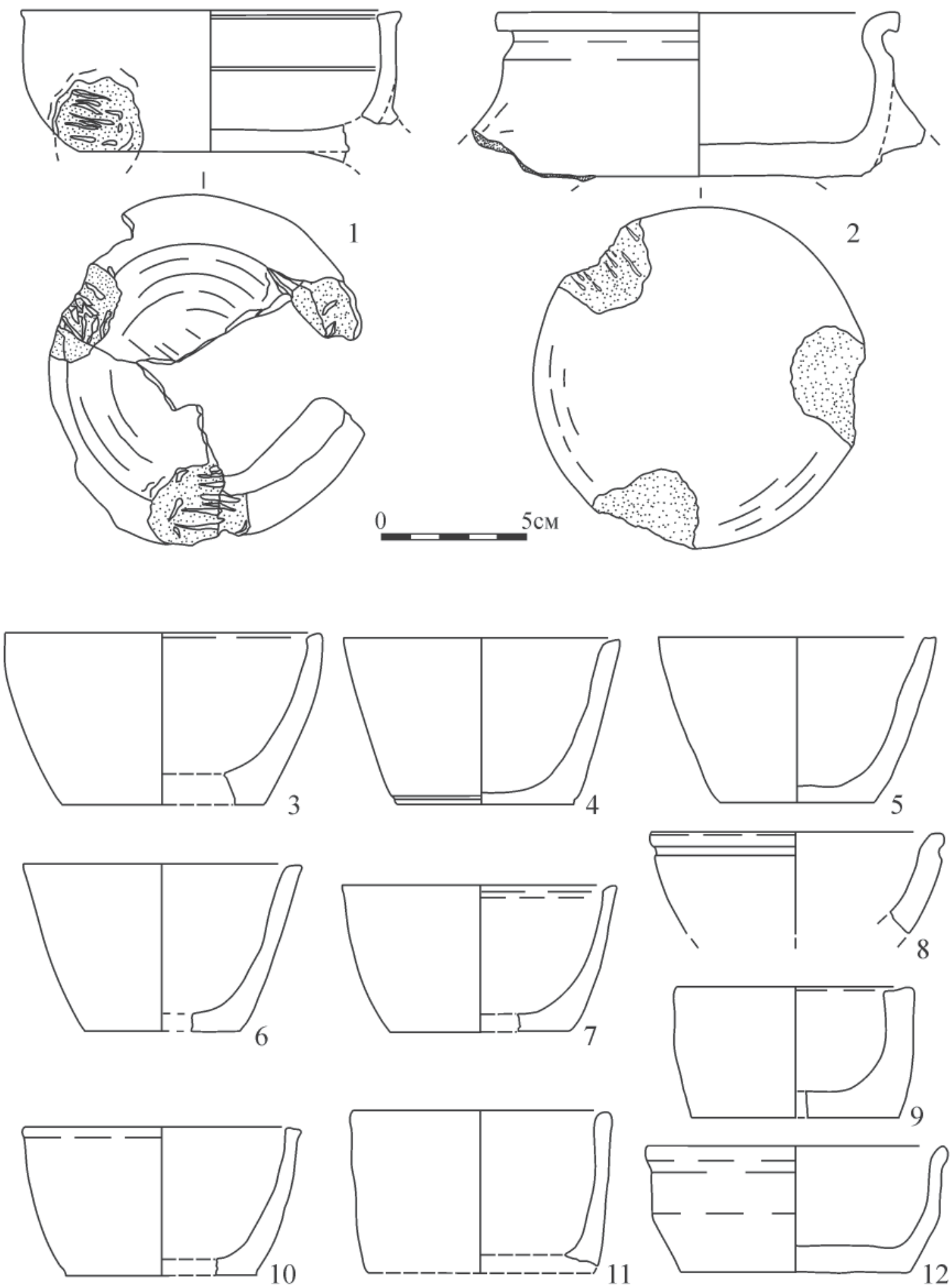

Рис. 6. Ритуальная посуда (графическая реконструкция): 1, 2 - триподы; 3-12 - чашечки-светильники

Fig. 6. Ritual dishes (graphic reconstruction): 1, 2-tripods; 3-12 - cups-lamps

в качестве светильников (лампадок?) (рис. 5: 4). Подобные чаши-светильники известны в материалах бохайских храмовых комплексов в Приморье (Копытинский, Краскинский) (Бохайские древности..., 2013, с. 97-99; Города средневековых..., 2018, с. 87).

К ритуальной посуде также относятся два небольших трипода. Первый трипод был реконструирован из фрагментов, найденных в разных частях раскопа (кв. И/2, И/5, 3/6, Г/8) (рис. 3, 5: 1; 6: 1). Размеры сосуда: высота 4,7 см, диаметр венчика 13,1 см, диаметр дна 8,0 см, толщина стенки 0,5 см, толщина дна 0,7 см. Венчик первого трипода прямой, имеет плоский, слегка отогнутый наружу край. Цвет черепка на внутренней и на внешней поверхности серый, в изломе светло-коричневый. Чаша трипода имеет следы вертикального 
лощения как с внутренней, так и с внешней стороны. На дне сосуда отмечены спиральные борозды - следы срезания с гончарного круга.

Второй трипод был обнаружен за пределами сооружения (кв. 3/13) (рис. 3, 5: 2; 6:2). Он немного крупнее, имеет черно-серый цвет поверхностей. Размеры изделия: высота 5,6 см, диаметр венчика 14 см, диаметр дна 12 cм, толщина стенок 0,6-1,1 см. Венчик отогнут наружу.

Чаши обоих триподов изготавливались на гончарном круге. К донной лепешке в процессе формовки прикреплялись стенки. Несмотря на то, что ножки у изделий обломаны, в зоне перехода стенки в дно прослеживаются следы их прикрепления в виде насечек и остатков укрепления дополнительной глиной.

Подобные триподы периодически встречаются на бохайских памятниках Приморья (Старореченское городище, Краскинское городище) (Слепцов и др., 2020, с. 514; Гельман, 2018 , с. 59), а также на некоторых памятниках с культовой архитектурой (Краскинский храмовый комплекс) (Города средневековых ..., 2018, c. 87).

Фрагменты станковой посуды немногочисленны и разрозненны. Изготавливалась такая керамика на гончарном круге и имеет четкий и ровный профиль. Формовочные массы данных сосудов хорошо выложенные, просеянные, с небольшим содержанием минерального отощителя в виде песка. Цвет черепка серый, светло-серый, серо-черный, поверхность их лощеная. Керамика в основном не орнаментирована, лишь на нескольких фрагментах отмечен декор в виде 1-2 прочерченных линий.

Металлические предметы составляют незначительную, но показательную часть коллекции, которая включает 16 экземпляров. Среди них есть изделия хорошей сохранности, имеющие прямые культурно-хронологические аналогии в материалах известных бохайских памятников.

Железная скоба найдена при разборке 1 пласта в квадрате Д/5. Представляет собой гнутый П-образный железный стержень, округлый в сечении с приостренными, прямоугольными в сечении, концами. Длина 16 см, ширина 11,4 см, толщина 0,9 см.

Внутренняя часть железного замка была найдена в квадрате Г/2 (2 пласт) (рис. 7: 1). Длина изделия 14,2 см, ширина 2 см, длина крепления с отверстием 5 см, ширина $1 \mathrm{~cm}$, в месте крепления - 1,5 см, диаметр отверстия $-0,7$ см. Запирающее устройство имеет два стержня с пружинами. Верхний стержень имеет две пластины-пружины, закрепленные с обеих сторон, а второй стержень - только одну пружину-пластину, развернутую перпендикулярно относительно пластин верхнего стержня. Данное запирающее устройство имеет более сложную конструкцию по сравнению с известными в Приморье подобными изделиями. Но в целом является одним из вариантов типа замков, запирающий механизм которых оснащен стержнем с пластинами-пружинами, и имеет аналогии на других бохайских памятниках (Асташенкова, 2017, с. 16-17).

Черешковый железный наконечник стре$\pi b l$ с плоским концом и сужающимся к основанию черешком-насадом найден в квадрате 3/6 (2 пласт) (рис. 7: 3). Наконечник в сечении прямоугольной формы, имеет размеры $6,6 \times 0,7 \times 0,3$ см. Длина черешка 2,7 см. Подобные наконечники - частая находка на средневековых памятниках. В существующей классификации бохайских наконечников Приморья он определяется как простой прямой срезень-лопаточка (тип 6, вариант Г) (Леньков, Шавкунов, 1993, с. 216, 219).

Фрагмент железного колокольчика найден в квадрате Д/12 (3 пласт) (рис. 7: 4). Сохранилась его верхняя часть, на которой видна деталь для крепления колокольчика и часть круглого отверстия. Этот артефакт обнаружен возле юго-восточного угла ограды кумирни, что не случайно, так как такие колокольчики обычно подвешивали по углам буддийских культовых сооружений.

Фрагмент чугунного углового колокола кумирни обнаружен на уровне 3 пласта в квадрате Ж/6 (рис. 7: 5). Представляет собой нижнюю часть одной из стенок шестигранного колокола с вогнутым основанием и сохранившимися углами еще двух стенок. Ширина нижней части стенки $5,4 \mathrm{~cm}$, толщина 0,4 см.

Колокольный вертлюг был найден при разборке 3 пласта в квадрате 3/5 (рис. 7: 2). Представляет собой железное перекрестие с остатками цепочки и кольца. Предназначался, по-видимому, для подвешивания углового колокола кумирни, о чем косвенно свидетельствует место его обнаружения - вблизи угла кумирни.

Металлическая пластина трапециевидной формы найдена в квадрате Л/11 на уровне 2 пласта. Пластина имеет размеры 6,6×1,5$3 \times 0,7$ см, оба ее конца обломаны.

В ходе раскопок обнаружен только один предмет из камня - это фрагмент постамента, изготовленного из розоватого слабо 

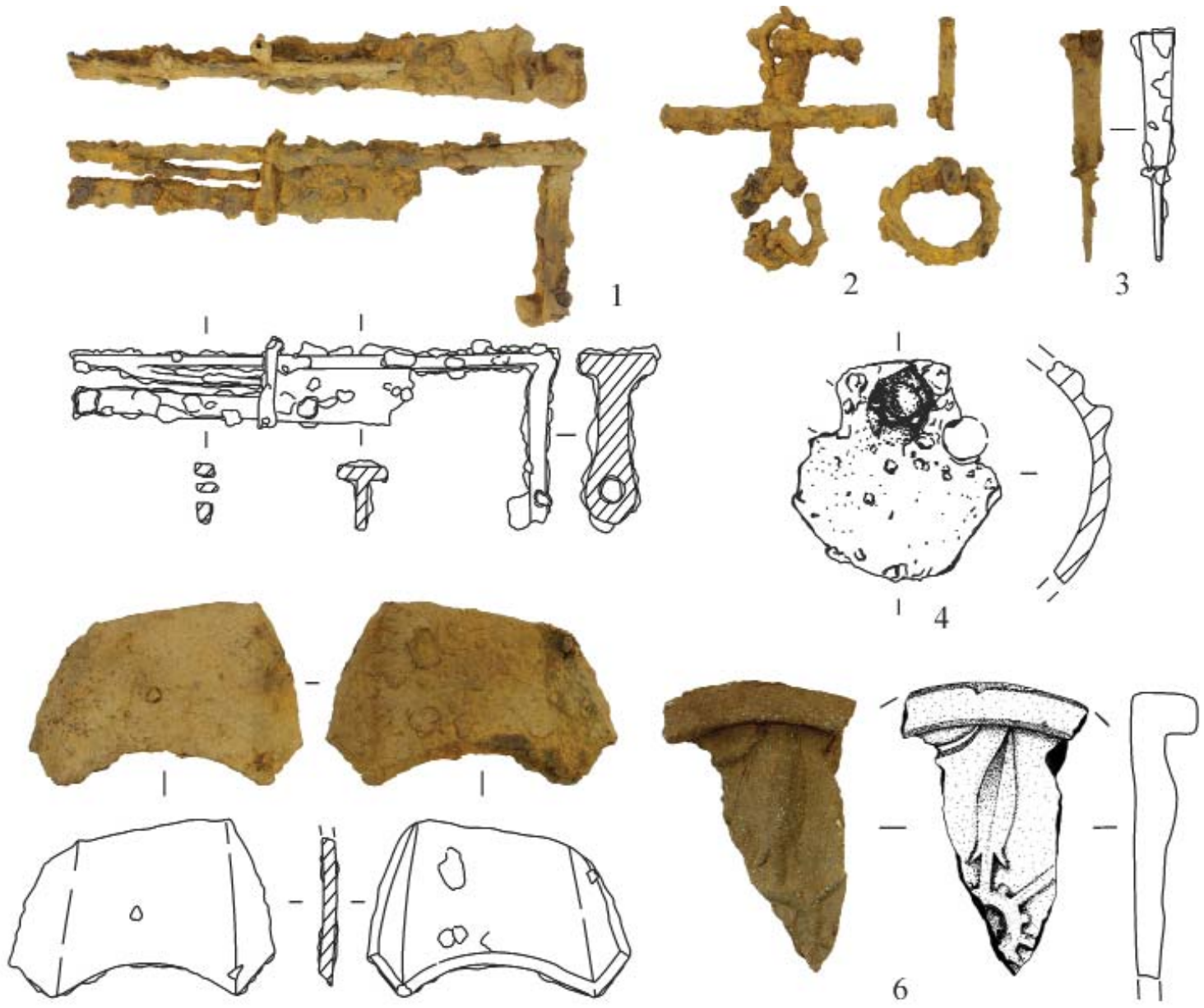

5
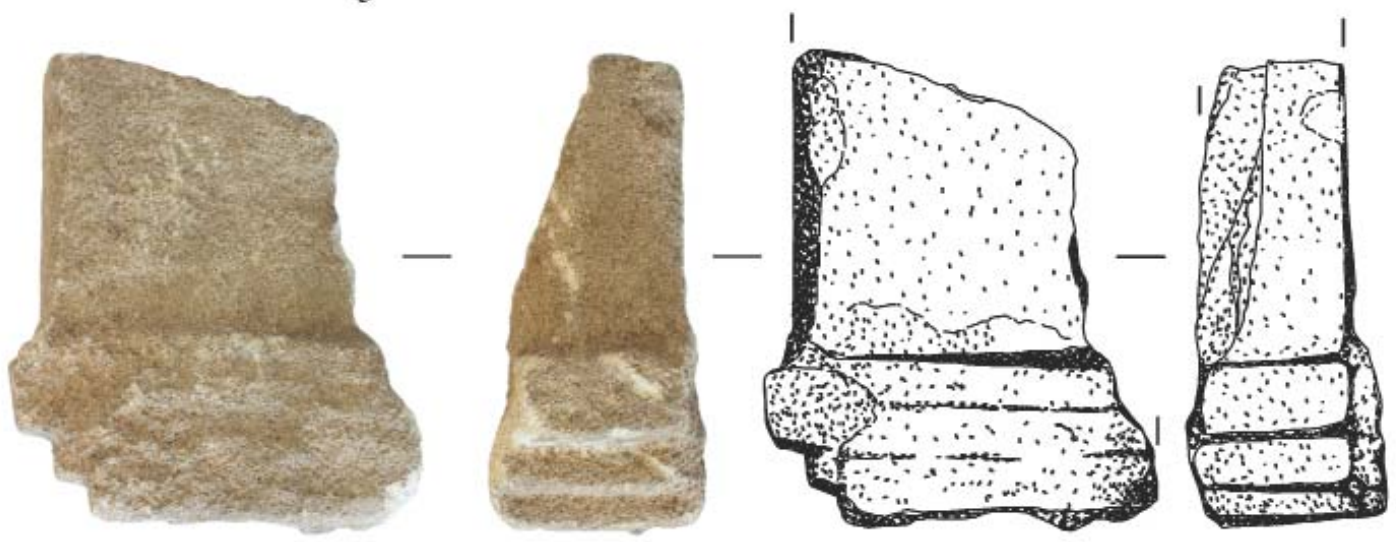

7

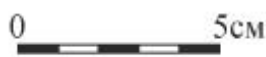

Рис. 7. 1 - внутренняя часть железного замка; 2 - колокольный вертлюг; 3 - наконечник стрелы; 4 - фрагмент железного колокольчика; 5 - обломок чугунного углового колокола кумирни; 6 - фрагмент концевого диска; 7 - обломок каменного постамента.

Fig. 7. 1 - inner part of the lock; 2 - bell swivel; 3 - arrowhead; 4 - a fragment of an iron bell; 5 - a fragment of corner of a cast-iron bell idolatry; 6 - a fragment of the end disk of the roof tiles; 7 - a fragment of a stone pedestal

метаморфизованного песчаника (рис. 7: 7). Изделие имеет подпрямоугольную форму, на боковом ребре выбраны поперечные геометрически правильные пазы, образующие три ступени. Размеры обломка - высота 12 см, ширина в основании $10 \mathrm{~cm}$, глубина 5 см. Возможно, данный обломок постамента мог являться основанием некой скульптуры.
Каменные и керамические буддийские скульптуры и их обломки известны на памятниках бохайского времени (Асташенкова, 2013).

В результате проведенных в 2010-2011 гг. работ на объекте «Барабаш-3. Кумирня» был полностью вскрыт периметр самой кумирни, ее ограды, а также остатки небольшого сооружения возле восточной стенки ограды. 
Вместе с тем стало понятно, что истинные размеры этого средневекового объекта больше вскрытой площади и выявленная кумирня является лишь частью ритуального буддийского комплекса. Полученные в ходе раскопок материалы имеют аналогии на других памятниках государства Бохай в Приморье и позволяют датировать комплекс VII-IX вв.

Исследования древних культовых построек являются одним из важных направлений в изучении религиозной жизни раннесредневекового населения. Известные на территории Приморья храмы бохайского времени чаще всего строились на возвышенных участках местности или на искусственной насыпной платформе. Как правило, культовые сооружения располагались за пределами городов и поселений (Копытинский, Абрикосовский, Корсаковский, Борисовский храмы), исключение составляет только Краскинский храмовый комплекс, находящийся на территории городища. Все храмы строились в соответствии с канонами китайской архитектуры и имели прямоугольную или квадратную в плане форму, и представляли собой здания колоннадного типа с черепичной крышей. Храмовые комплексы чаще всего были обнесены оградой и имели внутренний двор (Шавкунов, 1998, с. 75-91). Иногда на территории двора могли быть дополнительные сооружения - вспомогательные постройки, пагоды, барабанные (или колокольные) башни (Краскинский, Копытинский) (Города средневековых..., 2018, с. 135-136). Размеры культовых построек различны: самый крупный храм расположен на Краскинском городище, его площадь составляет 78,8 м² (Города средневековых..., 2018, с. 87), второй по размеру - Борисовский храм - его площадь $60 \mathrm{M}^{2}$ (Медведев, 1998, с. 248), размеры остальных бохайских храмов немного меньше: Абрикосовский -49 м ${ }^{2}$, Копытинский и Корсаковский

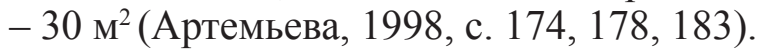

Раскопанное культовое сооружение «Барабаш-3. Кумирня» имеет некоторые аналогии с перечисленными храмовыми постройками. В первую очередь, сходство выражается в выборе места для строительства кумирни - на высокой оконечности мыса, в непосредствен- ной близости от небольшого бохайского селища Барабаш-4, расположенного на высокой пойменной террасе, примыкающей к мысу с востока (Археологические памятники..., 2008 , с. 275-281). Общая конфигурация культовой постройки квадратной в плане формы, наличие черепичной крыши, ограды и небольшого дополнительного сооружения на его территории также сближает данный комплекс с другими храмовыми сооружениями бохайского времени на территории Приморья. Найденный археологический материал, такой как обломки колоколец, ритуальная посуда, представленная чашечками-светильниками и триподами, находит прямые аналогии в материалах некоторых храмовых комплексов, в частности Краскинском и Копытинском (Города средневековых ..., 2018, с. 87; Бохайские древности..., 2013, с. 97-99).

Тем не менее имеется и ряд отличий культового комплекса «Барабаш-3. Кумирня» от упомянутых выше бохайских храмовых построек: это небольшие размеры самого сооружения, отсутствие колоннадной конструкции у здания, маленький внутренний двор. Судя по остаткам каменного фундамента, исследуемая кумирня представляла собой небольшой павильон площадью 18,5 $\mathrm{M}^{2}$ с четырьмя несущими столбами по углам и черепичной крышей. Вход в дворик был оформлен небольшими воротами шириной около 2 м с черепичным навесом.

Вероятно, крупные храмовые комплексы строились в окрестностях городов или на их территории, как в случае с Краскинским городищем. Прежде всего, они играли важную роль в распространении буддийского вероучения среди населения периферийной части государства Бохай, которой являлся Приморский регион, а также могли выполнять культурно-просветительские функции. Территория таких комплексов могла вмещать в себя большое количество людей, численность которых в городах была значительно выше. Исследованная же нами небольшая бохайская кумирня также выполняла религиознокультовые функции и вполне соответствовала нуждам жителей селища Барабаш-4, расположенного рядом.

\section{ЛИТЕРАТУРА}

Артемьева Н.Г. Культовые сооружения бохайского времени на территории приморья // РА. 1998. № 3. C. $175-190$.

Клюев Н.А., Хон Хён У, Гарковик А.В., Ким Дон Хун, Ким Дюэ Юн, Слепџов И.Ю., Мезенцев А.Л., Пискарев Я.Е., Никитин Ю.Г. Археологические памятники эпохи палеометалла и раннего средневе- 
ковья Приморья (по материалам исследований 2007 г.). Тэджон: Государственный исследовательский институт культурного наследия Республики Корея, 2008. 460 с.

Acташенкова E.B. Изображения Будд, бодхисатв и буддийских божеств в искусстве Бохая // Гуманитарные исследования в Восточной Сибири и на Дальнем Востоке. 2013. №5(25). С. 76-82.

Acmашенкова E.B. Замки и ключи из бохайских памятников Приморья // Труды III Международного конгресса средневековой археологии евразийских степей «Между Востоком и Западом: движение культур, технологий и империй» / Ред. Н.Н. Крадин, А.Г. Ситдиков. Владивосток: Дальнаука, 2017. С. $16-20$.

Aсташенкова E.B., Болдин В.И. Декор концевых дисков Краскинского городища // Россия и АТР. 2004. №1. C. 122-129.

Бохайские древности из Приморского края России. / Ред. Сун Юйбинь, А.Л. Ивлиев, Е.И. Гельман. Пекин Пекин: Вэньу, 2013. 278 с.

Гельман Е.И. Керамика Краскинского городища // Мультидисциплинарные исследования в археологии. 2018. № 2. С. 40-64.

Города средневековых империй Дальнего Востока / Отв. ред. Н.Н. Крадин. М.: Восточная литература, 2018. $367 \mathrm{c}$.

Государство Бохай (698-926 гг.) и племена Дальнего Востока России / Отв. ред. Э.В. Шавкунов М.: Наука, 1994. 219 с.

Клюев Н.А., Гридасова И.В. Памятник Барабаш-3: новые аспекты в изучении янковской археологической культуры в Приморье // Россия и АТР. 2013. №2 . С. 149-158.

Клюев Н.А., Якупов М.А., Слепцов И.Ю. Исследования новой бохайской кумирни в Приморье // Труды III (XIX). Всероссийского археологического съезда. Т. II. / Ред. Н.А. Макаров, Е.Н. Носов. Великий Новгород-Старая Русса: ИИМК РАН. 2011. С. 47-48.

Леньков В.Д., Шавкунов В.Э. Железные наконечники стрел бохайцев Приморья // Военное дело населения юга Сибири и Дальнего Востока / Отв. ред. В.Е. Медведев, Ю.С. Худяков. Новосибирск: Наука, 1993. С. 214-226.

Медведев В.E. Бохайская кумирня в Приморье. Сеул: Изд-во Хакъёнмунхваса, 1998. 477 с.

Слепиов И.Ю., Клюев Н.А., Прокопеи С.Д., Белова И.В., Белов Д.М. Раскопки на городище Старореченское в Приморье // Археологические открытия. 2018 год. / Отв. ред. Н.В. Лопатин. М.: ИА РАН, 2020. С. 512-515.

Стоякин M.A. Буддийская культовая архитектура бохайского времени в северной части Корейского полуострова // Вестник НГУ. Серия: История, филология. 2012. Т. 11. № 3. С. 262-267.

Шавкунов Э.В. Государство Бохай и памятники его культуры в Приморье. Л.: Наука, 1968. 168 с.

\section{Информация об авторах:}

Клюев Николай Александрович, кандидат исторических наук, доцент, ведущий научный сотрудник, зав. Сектором первобытной археологии, зам. директора по научной работе, Институт истории, археологии и этнографии народов Дальнего Востока ДВО РАН (г. Владивосток, Росcия); kluyev2006@ yandex.ru

Прокопец Станислав Данилович, кандидат исторических наук, старший научный сотрудник, Институт истории, археологии и этнографии народов Дальнего Востока ДВО РАН (г. Владивосток, Россия); stas842005@mail.ru

Слепцов Игорь Юрьевич, младший научный сотрудник, Институт истории, археологии и этнографии народов Дальнего Востока ДВО РАН (г. Владивосток, Россия); igorslep@yandex.ru

Белова Ирина Владимировна, младший научный сотрудник, Институт истории, археологии и этнографии народов Дальнего Востока ДВО РАН (г. Владивосток, Россия); irceo@mail.ru

\section{REFERENCES}

Artemeva, N. G. 1998. In Rossiiskaia Arkheologiia (Russian Archaeology) (3), 175-190 (in Russian).

Klyuev, N. A., Hong Hyun Woo, Garkovik, A. V., Kim Dong-Hoon, Kim Jae Yoon, Sleptsov, I. Yu., Mezentsev, A. L., Piskareva, Ya. E., Nikitin, Yu. G. 2008. Arkheologicheskie pamiatniki epokhi paleolita $i$ rannego srednevekov'ia Primor'ia (po materialam issledovanii $2007 \mathrm{~g}$. (Archaeological Monuments of the Palaeometal Period and the Early Middle Ages of Primorye (Based on Study Materials of 2007)). Daejeon: State Research Institute of Cultural Heritage of the Republic of Korea (in Russian).

Astashenkova, E. V. 2013. In Gumanitarnye issledovaniia v Vostochnoi Sibiri i na Dalnem Vostoke (Humanitarian Studies in Eastern Siberia and the Far East) 25 (5), 76-82 (in Russian). 
Astashenkova, E. V. 2017. In Kradin, N. N., Sitdikov, A. G. (eds.). Trudy III Mezhdunarodnogo kongressa srednevekovoi arkheologii evraziiskikh stepei "Mezhdu Vostokom i Zapadom: dvizhenie kul'tur, tekhnologii i imperii" (Preceedings of $3^{\text {rd }}$ International Congress on Medieval Archaeology of Eurasian Steppes "Between the East and the West: Movements of Cultures, Technologies and Empires"). Vladivostok: "Dal'nauka" Publ., 16-20 (in Russian).

Astashenkova, E. V., Boldin, V. I. 2004. In Rossiya i ATR (Russia and Asia-Pacific Region) 1, 122-129 (in Russian).

Song Yubin, Ivliev, A.L., Gel'man, E.I. (eds.). Bokhaiskie drevnosti iz Primorskogo kraia Rossii (The Bohai Antiquities from the Primorye Region of Russia). Beijing: Wenwu Publ., 2013 (in Russian, and in Chinese).

Gel'man, E. I. 2018. In Mul'tidistsiplinarnye issledovaniia $v$ arkheologii (Multidisciplinary Studies in Archaeology) (2), 40-64 (in Russian).

Kradin, N. N. 2018. (ed.). Goroda srednevekovykh imperiy Dal'nego Vostoka (Towns of the Medieval Empires of the Far East). Moscow: "Vostochnaya literatura" Publ. (in Russian).

Shavkunov, E. V. 1994. (ed.). Gosudarstvo Bokhai (698-926 gg.) i plemena Dal'nego Vostoka Rossii (Bohai State (698-926) and the Tribes of the Russian Far East.). Moscow: "Nauka" Publ. (in Russian).

Klyuev, N. A., Gridasova, I. V. 2013. In Rossiya i ATR (Russia and Asia-Pacific Region) 2, 149-158 (in Russian).

Klyuev, N. A., Yakupov, M. A., Sleptsov, I. Yu. 2011. In Makarov, N. A., Nosov, E. N. (eds.). Trudy III (XIX). Vserossiiskogo arkheologicheskogo s"ezda. Velikii Novgorod - Staraia Russa (Proceedings of the $3^{\text {rd }}$ $\left(19^{\text {th }}\right)$. All-Russian Archaeological Meeting. Veliky Novgorod - Staraya Russa). 2. Saint Petersburg; Moscow; Velikiy Novgorod: Institute for the History of Material Culture, Russian Academy of Sciences, 47-48 (in Russian).

Len'kov, V. D., Shavkunov, V. E. 1993. In Medvedev, V. E., Khudiakov Yu. S. (eds.). Voennoe delo naseleniia inga Sibiri i Dal'nego Vostoka (Warfare of the Population of Southern Siberia and Russian Far East). Novosibirsk: "Nauka" Publ., 214-226 (in Russian).

Medvedev, V. E. 1998. Bokhaiskaia kumirnia v Primor'e (Bohai Idol Temple in Primorye). Seul: "Hakyenmunhwasa" Publ. (in Russian, in Korenian).

Sleptsov, V. V., Kliuev, N. A., Prokopets, S. D., Belova, I. V., Belov, D. M. 2020. In Lopatin, N. V. (ed.). Arkheologicheskie otkrytiia 2018 g. (Archaeological Discoveries of 2018) Moscow: Institute of Archaeology, Russian Academy of Sciences, 512-515 (in Russian).

Stoyakin, M. A. 2012. In Vestnik Novosibirskogo Gosudarstvennogo universiteta. Istoriia, filologiya (Bulletin of the Novosibirsk State University: History, Philology) 11 (3), 262-267 (in Russian).

Shavkunov, E. V. 1968. Gosudarstvo Bokhai i pamiatniki ego kul'tury v Primor'e (Bohai State and the Monuments of its Culture in Primorye). Leningrad: "Nauka" Publ. (in Russian).

\section{About the Authors:}

Kluyev Nikolay A. Candidate of Historical Sciences, Associate Professor, Institute of History, Archaeology and Ethnography of the Peoples of the Far East of the Far Eastern Branch of the Russian Academy of Sciences. Pushkinskaya St., 89, Vladivostok, 690001, Russian Federation; kluyev2006@yandex.ru

Prokopets Stanislav D. Candidate of Historical Sciences, Institute of History, Archaeology and Ethnography of the Peoples of the Far East of the Far Eastern Branch of the Russian Academy of Sciences. Pushkinskaya St., 89, Vladivostok, 690001, Russian Federation; stas842005@mail.ru

Sleptsov Igor Yu. Institute of History, Archaeology and Ethnography of the Peoples of the Far East of the Far Eastern Branch of the Russian Academy of Sciences. Pushkinskaya St., 89, Vladivostok, 690001, Russian Federation; igorslep@yandex.ru

Belova Irina V. Institute of History, Archaeology and Ethnography of the Peoples of the Far East of the Far Eastern Branch of the Russian Academy of Sciences. Pushkinskaya St., 89, Vladivostok, 690001, Russian Federation; stas842005@mail.ru

Статья поступила в журнал 01.04.2021 г. Статья принята к публикации 01.04.2021 г. Авторы внесли равноценный вклад в работу. 